\title{
The Influence of Reasonableness on the Element of Conduct in Delictual or Tort Liability - Comparative Conclusions
}

\section{P.E.R}

Pioneer in peer-reviewed, open access online law publications

Author

Raheel Ahmed

Affiliation

University of South Africa

Email ahmedr@unisa.ac.za

Date Submission

8 March 2019

Date Revised

11 August 2019

Date Accepted

19 August 2019

Date published

7 October 2019

Editor Dr A Gildenhuys

How to cite this article

Ahmed R "The Influence of

Reasonableness on the Element of Conduct in Delictual or Tort Liability - Comparative Conclusions" PER / PELJ 2019(22) - DOI

http://dx.doi.org/10.17159/17273781/2019/v22i0a6122

\section{Copyright}

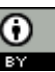

DOI

http://dx.doi.org/10.17159/1727-

3781/2019/v22i0a6122

\begin{abstract}
In this contribution the influence of reasonableness on the element of conduct in the South African law of delict will be analysed and compared with the requirement of some form of conduct in English tort law, American tort law and the French law of delict.
\end{abstract}

Fundamental similarities and differences among the different legal systems must be considered. France and South Africa follow a generalising approach to determining a delict while English and American law have a system of separate torts.

Even though English and American law do not explicitly refer to the requirement of conduct in tort law, it is generally implicitly required. This is the case whether one is dealing with the tort of negligence or the intentional torts. In French law too, a fait générateur (a generating, triggering, wrongful act or event) generally must also be present in order to ground delictual liability. The concept of fait générateur is broader than the concept of conduct found in the other jurisdictions in that it extends beyond what is regarded as human conduct. The conduct in all the jurisdictions may be in the form of a commission (a positive, physical act or statement) or an omission (a failure to act). The requirement that conduct must be voluntary is generally found in South African, English and American law (with an exception applying to mentally impaired persons) but not in France. Naturally, it is unreasonable to hold a person liable without conduct which results in the causing of harm or loss. In all the above-mentioned jurisdictions, it would generally be unreasonable to hold the wrongdoer liable in delict or tort law if the omission or commission does not qualify as some form of conduct. Thus the influence of reasonableness on the element of conduct in all the above-mentioned jurisdictions is implicit.

\section{Keywords}

American law; conduct; commission; delict; English law; French law; involuntary; omission; reasonableness; South African law; tort; voluntary. 


\section{Introduction}

Much uncertainty about the role of reasonableness has surfaced in the South African case law lately, particularly with regard to the elements of wrongfulness and fault in determining delictual liability. This has prompted me to undertake research in order to ascertain the influence of reasonableness on the elements of delictual liability. In previous contributions $^{1}$ the historical development of the concept "reasonableness", its definition, its modern uses and its interrelatedness with other jurisprudential concepts in the law of delict were discussed. In this contribution the influence of reasonableness on the element of conduct ${ }^{2}$ in determining delictual liability in South African law will be analysed and compared with the influence of reasonableness on the requirement of some form of conduct in English tort law, ${ }^{3}$ American tort law ${ }^{4}$ and the French law of delict.

France and the United Kingdom have produced two major legal systems of the world, both of which have influenced many other legal systems. ${ }^{5}$ The French Civil Code of 1804 was the basis for civil law in Italy, Belgium, Luxembourg, Netherlands, Poland, Spain, Portugal and some African countries. ${ }^{6}$ For this reason, French law, as one of the most influential systems in the civil law tradition, is a good choice for comparative research, in addition to the law of the United Kingdom (hereinafter referred to as English law) and the law of the United States of America (hereinafter referred to as American law). The United States of America and the United

Raheel Ahmed. LLB LLM LLD (UNISA). Admitted Attorney, Conveyancer and Notary of the High Court of South Africa. Senior Lecturer, Department of Private Law, University of South Africa. E-mail: ahmedr@unisa.ac.za. This contribution is based on material taken from various chapters of my LLD thesis The Explicit and Implicit Influence of Reasonableness on the Elements of Delictual Liability. Thank you to my employer, the University of South Africa, for awarding me the "Academic Qualification Improvement Programme" grant. The grant enabled me to research English tort law, American tort law and the French law of delict, and to complete the thesis. Thank you also to my supervisor Prof JC Knobel for his valuable guidance.

$1 \quad$ Ahmed 2019a THRHR 257 and Ahmed 2019b THRHR 381. This current contribution is the third contribution in a series of contributions based on the influence of reasonableness on the elements of delictual liability.

2 The influence of reasonableness on the other individual elements of delictual liability will be discussed further in later contributions still to be published.

$3 \quad$ The word "tort" is synonymous with the word "delict". The term "English law" here refers to the law of the United Kingdom.

$4 \quad$ The term "American law" here refers to the law of the United States of America. Van Dam European Tort Law 9.

Van Dam European Tort Law 52; Van Gerven, Lever and Larouche Tort Law 5. 
Kingdom represent the common law family, ${ }^{7}$ while France represents the civil law family. ${ }^{8}$ Zweigert and Kötz ${ }^{9}$ point out that even though American law is based on English law, it has developed its own style and it would be a mistake not to include it in a comparative study. The mix of English law and American law is commonly referred to as Anglo-American law. This term will be used herein when referring to English and American law. This choice of jurisdictions should produce insights from a variety of perspectives in respect of the influence of reasonableness on the law of delict or tort law.

It is useful to begin with a brief explanation of the fundamental differences and similarities between the legal systems of the above-mentioned jurisdictions. Thereafter, the influence of reasonableness on some form of conduct in each of these jurisdictions will be analysed. In conclusion the similarities and differences between the influences of reasonableness on some form of conduct in the jurisdictions will be highlighted.

\section{Fundamental differences and similarities among the different legal systems}

In general, English common law has influenced South African law. ${ }^{10}$ English law has also influenced American law. However, since the United States of America declared its independence from Britain in 1776, its law has undergone change, particularly due to the adoption of a written constitution. ${ }^{11}$ Social and economic development in the United States of America has also influenced the development of law. ${ }^{12}$

Roman-Dutch law was introduced into South Africa by the Dutch in the seventeenth century. ${ }^{13}$ The South African law of delict is therefore a mix of

7 Common law is based on case law that developed over time. Adjudicators refer to prior existing decisions. English and American law is based on common law and therefore form part of the common law family. See Zweigert and Kötz Introduction to Comparative Law 41, 69.

8 In respect of the civil law tradition, the law ruling the jurisdiction is codified. Adjudicators need not refer to prior existing decisions but refer to the codified law. In France, the adjudicators refer to the French Civil Code of 1804 (CC) and therefore French law, like German law (the Bürgerliches Gesetzbuch - the Civil Code of Germany) forms part of the civil law family. See Zweigert and Kötz Introduction to Comparative Law 69, 74, 143-144.

$9 \quad$ Zweigert and Kötz Introduction to Comparative Law 41.

$10 \quad$ See Hahlo and Khan South African Legal System 575-578.

11 Constitution of the USA. The Constitution encompasses basis rights which generally cannot be infringed by the legislature, the executive or the judiciary. The country also has a federal structure. See Zweigert and Kötz Introduction to Comparative Law 219, 239.

$12 \quad$ Zweigert and Kötz Introduction to Comparative Law 239.

13 Zweigert and Kötz Introduction to Comparative Law 231. 
English common law and Roman-Dutch law. ${ }^{14}$ It is for this reason, coupled with South Africa's adoption of a written constitution ${ }^{15}$ and recognition of the applicability of South African customary law, ${ }^{16}$ that South African law is now referred to as a hybrid system or mixed jurisdiction. ${ }^{17}$

Like Roman law, the common law of torts initially developed with specific categories of liability, but on the continent, a general approach in determining liability was followed. ${ }^{18}$ This general approach is followed in South African and French law. ${ }^{19}$ The Anglo-American law kept to the tradition of separate torts which was developed under the writ system. ${ }^{20}$ Each separate tort is independent, has its own elements, its own possible defences, and protects particular interests. ${ }^{21}$ There are many torts in AngloAmerican law. For example, English law has approximately seventy torts. ${ }^{22}$ Due to the fact that Anglo-American law differentiates between many intentional torts and the tort of negligence, only the tort of negligence and the torts of trespass to the person will be considered. ${ }^{23}$ The torts of trespass to the person include the tort of battery, the tort of assault, and the tort of false imprisonment.

South African, English and American law follow the precedent system due to the common law influence on the law of civil procedure. ${ }^{24}$ Thus, adjudicators ${ }^{25}$ decide on whether a delict or tort was committed, whether a defence is applicable in limiting or excluding liability, and the amount of compensation that should be awarded to the plaintiff. Constitutions, legislation, international treaties and conventions in conjunction with the

$14 \quad$ Zweigert and Kötz Introduction to Comparative Law 231.

15 The Constitution of the Republic of South Africa, 1996.

16 Provided it is consistent with the constitutional provisions and has not been affected by legislation. See ss 211 and 13(2) of the Constitution of the Republic of South Africa, 1996; S v Makwanyane 19956 BCLR 665 (CC) paras 365-383; Van der Walt and Midgley Principles of Delict 30 fn 3-5; Himonga and Nhlapo African Customary Law 45-46.

$17 \quad$ Zweigert and Kötz Introduction to Comparative Law 72, 235.

18 See Zweigert and Kötz Introduction to Comparative Law 605.

19 As will be shown in this contribution and further contributions.

$20 \quad$ Zweigert and Kötz Introduction to Comparative Law 605.

$21 \quad$ Zweigert and Kötz Introduction to Comparative Law 605.

22 See Koziol "Comparative Conclusions" 697.

23 The torts of trespass to the person are important intentional torts to consider with regard to bodily harm caused intentionally. The torts of trespass to the person were also chosen in order to meaningfully compare the influence of reasonableness with regard to intentionally inflicted harm or loss in Anglo-American tort law and in the South African law of delict.

$24 \quad$ See Zweigert and Kötz Introduction to Comparative Law 232.

25 In the United States of America, where a jury is appointed it is regarded as the trier of facts (Dobbs, Hayden and Bublick Hornbook on Torts 36). 
common law may play roles in determining delictual liability or liability in tort law. ${ }^{26}$ The French law of delict is based primarily on the French Civil Code of 1804. The precedent system is not followed in the French law of civil procedure. Thus French adjudicators need not refer to prior decisions. ${ }^{27}$

Even though Anglo-American law does not follow a generalising approach as in South Africa and France, in all these jurisdictions, generally, as will be shown below, some form of conduct is required and inferred from the facts in order to ground liability in delict or tort law.

South African, English and American law generally refer to "reasonableness" in considering a number of elements of delictual or tort liability. In France the concept is not explicitly referred to but the concepts of solidarity, liberty and equality are. ${ }^{28}$ "Reasonableness" is considered implicitly, however, where other terms or phrases reflecting reasonableness values or standards are used. Fletcher ${ }^{29}$ correctly points out that while jurisdictions following common law such as the United Kingdom and the United States of America easily refer to the concept "reasonableness", other jurisdictions (like France) rarely do, but that does not mean that lawyers of the different jurisdictions think differently. It just means that they speak differently.

\section{The influence of reasonableness on the element of conduct in the South African law of delict}

Conduct is defined as a "voluntary human act or omission". ${ }^{30}$ From this definition it is apparent that conduct may be in the form of an omission (a failure to act) or a commission (a positive, physical act or statement). ${ }^{31}$ The act or omission generally must have been committed by a human being ${ }^{32}$

26 See Dobbs, Hayden and Bublick Hornbook on Torts 3 with reference to American law.

27 See Borghetti 2012 JETL 180; Van Dam European Tort Law 55.

28 The main aim of the $\mathrm{CC}$ is to affirm liberty, equality and fraternity (Van Dam European Tort Law 51).

29 Fletcher 1985 Harv L Rev 949-953.

$30 \quad$ Neethling and Potgieter Law of Delict 25; Van der Walt and Midgley Principles of Delict 90; Loubser and Midgley Law of Delict 95.

31 Van der Walt and Midgley Principles of Delict 92; Loubser and Midgley Law of Delict 95; Burchell Principles of Delict 37.

32 In instances where a human being uses an animal as an instrument to commit a delict, such conduct will be considered a human act, qui facit per alium facit per se he who acts through another commits the act himself (Burchell Principles of Delict 37). See Jooste v Minister of Police 19751 SA 349 (E) 354, where Addleson J referred to instances where the police make use of dogs just as they use "other suitable and appropriate instruments". In this case a police dog bit and injured a boy 
or a juristic person such as a close corporation or company, ${ }^{33}$ and the act must be voluntary. ${ }^{34}$

Voluntariness refers to the person's mental ability to control his muscular movements. ${ }^{35}$ A person's conduct need not be reasonable or desired in order to be voluntary. ${ }^{36}$ There are certain recognised conditions which may result in an act's being regarded as involuntary. For example, absolute compulsion, ${ }^{37}$ being unconsciousness or in a state of sleep, ${ }^{38}$ extreme intoxication, ${ }^{39}$ reflex muscular movements, black-outs, ${ }^{40}$ fits, ${ }^{41}$ severe emotional pressure ${ }^{42}$ heart attacks, ${ }^{43}$ hypnosis, and mental impairments, ${ }^{44}$ are all regarded as conditions which may render one's actions involuntary while in such condition. ${ }^{45}$ Automatism in South African law is the well-known defence which refutes the imputation that an act or omission was voluntary. ${ }^{46}$ The defence of automatism will not succeed if the defendant negligently or intentionally created the situation in which he claims to have

in the course of an arrest. The court found that the circumstances did not call for the use of the dog, which was not justified. The court awarded damages to the boy's father, in his capacity as father and natural guardian, for the harm suffered by the son. Also see Neethling and Potgieter Law of Delict 25; Van der Walt and Midgley Principles of Delict 90; Loubser and Midgley Law of Delict 96. Which can be held delictually liable through the actions of its organs, who are people. See Neethling and Potgieter Law of Delict 25-26; Van der Walt and Midgley Principles of Delict 90; Loubser and Midgley Law of Delict 96. Neethling and Potgieter Law of Delict 25; Van der Walt and Midgley Principles of Delict 90-91; Loubser and Midgley Law of Delict 96. Neethling and Potgieter Law of Delict 26; Van der Walt and Midgley Principles of Delict 91; Loubser and Midgley Law of Delict 96. Neethling and Potgieter Law of Delict 26; Loubser and Midgley Law of Delict 96.

See $S v$ Goliath 19723 SA 1 (A).

See $R v$ Dhlamini 19551 SA 120 (T).

See $S v$ Chretien 19811 SA 1097 (A). If a person consumes alcohol while foreseeing that he might drive a motor vehicle later on, his conduct will still be considered voluntary even though at the time of the accident he was so inebriated that his actions were in actual fact involuntary. See Visser "Compensation for Pecuniary Loss" 1096.

See Government v Marine and Trade Insurance Co Ltd 19733 SA 797 (D); Molefe $v$ Mahaeng 19991 SA 562 (SCA). See $R v$ Mkize 19592 SA $260(\mathrm{~N})$.

See $S$ v Arnold 19853 SA 256 (C).

See Gabellone $v$ Protea Assurance Ltd 19814 SA 171 (O).

See $S$ v Mahlinza 19671 SA 408 (A). Conduct by a person living with a mental disability or an infant is generally voluntary, but such person may not be held delictually liable due to the exclusion of fault or lack of accountability. See Neethling and Potgieter Law of Delict 26; Van der Walt and Midgley Principles of Delict 90-91; Loubser and Midgley Law of Delict 96-97. See Neethling and Potgieter Law of Delict 27; Loubser and Midgley Law of Delict 97; Van der Walt and Midgley Principles of Delict 91; Burchell Principles of Delict 23. See Government v Marine and Trade Insurance Co Ltd 19733 SA 797 (D) 799; Molefe v Mahaeng 19991 SA 562 (SCA); Ahmed "Influence of Reasonableness" 50 and the authority cited therein. 
behaved involuntarily. ${ }^{47}$ With regard to the alleged negligent conduct of the defendant, what must be determined "is whether the reasonable person in the position of the defendant would have foreseen the possibility of the ensuing harm while in a state of automatism and would have prevented such harm". ${ }^{48}$ For example, if a defendant who is prone to epileptic fits forgets to take his medication one morning and it later transpires that he suffered an epileptic fit while driving, thereby causing an accident, ${ }^{49}$ he cannot rely on automatism. The courts take into account the defendant's conduct prior to the state of automatism. ${ }^{50} \mathrm{~A}$ reasonable person in the position of the defendant would have taken his medication, thus preventing the occurrence of a fit which resulted in the ensuing harm. ${ }^{51}$ In trying to

47 Neethling and Potgieter Law of Delict 28-29; Ahmed "Influence of Reasonableness" 50.

48 This question brings us to the element of fault and effectively another incidence of conduct - that is the omission to take prescribed medication. See Ahmed "Influence of Reasonableness" 50. See Neethling and Potgieter Law of Delict 28; Van der Walt and Midgley Principles of Delict 91; Burchell Principles of Delict 36-37. Which resulted in the injury of an innocent victim. Gabellone v Protea Assurance Ltd 19814 SA 171 (O) 173-174. Van der Merwe and Olivier Die Onregmatige Daad in die Suid-Afrikaanse Reg 26-29 submit that automatism does not exclude conduct, but rather wrongfulness or fault. Their view may be illustrated with reference to the example in the text above in that the actual conduct which led to the accident was not voluntary, but there were prior voluntary acts (or, in the example, an omission to take medication) which caused the innocent victim's injury. They submit that the conduct was voluntary but that fault is absent, resulting in no delictual liability. Neethling and Potgieter (Law of Delict 29) admit that this view may be theoretically correct, but criticise it on the ground that it conforms to a narrow view of automatism, and also that the plaintiff may have difficulty in proving negligence. The latter authors are of the view that one must look at the act which caused the harm (not the prior acts) and if it is involuntary then there is no "conduct". If, however, the defendant knew or should have reasonably foreseen that his omission could cause harm, he will not be able to rely on automatism because his liability will be based on his prior conduct.

51 See Molefe $v$ Mahaeng 19991 SA 562 (SCA), where the defendant suffered a blackout raising automatism as a defence and succeeded. Even though the defendant had slipped and fallen earlier on the day of the accident, the court held that there was a lack of evidence in proving that the reasonable person should have been aware of the possibility of a blackout as a result of the fall earlier that day (569). In this case, the court followed a similar approach to that in English law (with regard to the tort of negligence), where the standard applied is the "reasonable person" and fault in the form of negligence is absent. English tort doctrine generally does not differentiate between the element of conduct and fault. See Mansfield $v$ Weetabix 19881 WLR 1263 (CA). Mullender 2005 MLR 688, however, with regard to Anglo-American law agrees that in such instances the defendant does not act. In Wessels v Hall and Pickles (Coastal) (Pty) Ltd 19854 SA 153 (C) 158, the defendant suffered a hypoglycaemic attack resulting in a diabetic coma while driving and causing an accident. The court held that the defendant was negligent for failing to take precautions by eating a mid-morning snack in his insulin-dependent diabetic condition. The reasonable person would have foreseen the possibility that if he missed his mid-morning snack, his blood sugar level might have dropped unexpectedly, thereby causing him to lose control of the vehicle. But see Gabellone 
ascertain whether the conduct was voluntary, the courts consider the conduct, prior to the state of automatism, of the hypothetical reasonable person in a position similar to that of the defendant. This relates to negligence. ${ }^{52}$ Similarly, with reference to the example above, intentional conduct may be considered. Thus, if the defendant intentionally and deliberately does not take his medication one morning, leading to him suffering an epileptic fit while driving, thereby causing an accident, it is doubtful that he will be able to rely on automatism. The doctrine actio libera in causa ${ }^{53}$ may be applied and the defendant may be held liable for any harm or loss suffered by the plaintiff. ${ }^{54}$

The influence of reasonableness on conduct is implicit. ${ }^{55}$ It is in principle reasonable to hold a defendant liable in delict only if the element of conduct is present with all the other required elements. ${ }^{56}$ It is reasonable to hold a person liable in South African law only if the voluntary conduct was present in the form of an act or omission and was undertaken by a human being. ${ }^{57}$ Naturally, if the conduct was not undertaken by a human being or was involuntary, then it is unreasonable to hold the defendant liable, as there is no conduct. ${ }^{58}$ In cases where an animal is used as an instrument by a human being to commit a delict, then it may be deemed a human act, as the human being is in control of the animal. ${ }^{59}$ In a similar vein, conduct by a natural person acting as an organ of a juristic person may be deemed

v Protea Assurance Ltd 19814 SA 171 (O) 173-174, where the driver suffered from coronary thrombosis prior to his death and subsequently suffered a cardiac disturbance which affected his ability to control the vehicle he was driving shortly before the accident. The court held that what happened thereafter was "not due to any voluntary action or inaction on his part." Edeling AJ found that on the balance of probabilities the (deceased) driver, at the time of the accident, suffered a heart attack which was not due to his negligence (174). Also see Neethling and Potgieter Law of Delict 28-29; Van der Walt and Midgley Principles of Delict 91; Loubser and Midgley Law of Delict 98.

$52 \quad$ Loubser and Midgley Law of Delict 98-99; Ahmed "Influence of Reasonableness" 50.

53 The wrongdoing he commits can be imputed to him for actions unfree in themselves, but free in their causes.

$54 \quad$ Neethling and Potgieter Law of Delict 28; Van der Walt and Midgley Principles of Delict 91; Loubser and Midgley Law of Delict 97.

55 Ahmed "Influence of Reasonableness" 50.

56 Ahmed "Influence of Reasonableness" 50.

$57 \quad$ See Neethling and Potgieter Law of Delict 25; Van der Walt and Midgley Principles of Delict 90; Loubser and Midgley Law of Delict 95.

58 Except in instances where the actio de pastu and the actio de pauperie are applicable. See Neethling and Potgieter Law of Delict 381-385.

$59 \quad$ See Neethling and Potgieter Law of Delict 25; Van der Walt and Midgley Principles of Delict 90; Loubser and Midgley Law of Delict 96. 
human conduct and it may be reasonable to hold the defendant liable, provided all the other elements of a delict are present too. ${ }^{60}$

Generally, in determining whether conduct is present the adjudicator will consider the facts of the case. It is predominantly a factual enquiry. However, in the requirement that the conduct must be voluntary, normative elements become more prominent. In principle, if the conduct is voluntary, then conduct may be present and it is reasonable to hold the defendant liable in delict, providing all the other elements are proved. In respect of the defence of automatism, it may be argued that it is reasonable for the defence to apply, if the person was mentally unable to control his muscular movements. Thus, if the defendant was mentally able to control his muscular movements then in principle his conduct may be considered voluntary, the defence of automatism will not be applicable, and it is reasonable to hold the defendant delictually liable. As already stated, automatism will not succeed if the defendant's prior intentional or negligent conduct led to the involuntary bodily movements which resulted in harm to the plaintiff. It would thus be unreasonable for automatism to succeed as a defence to the element of conduct if the defendant's prior negligent or intentional conduct led to the subsequent involuntary bodily movements which resulted in harm to the plaintiff.

\section{The influence of reasonableness on conduct in English law}

\subsection{The intentional torts of trespass ${ }^{61}$ to the person}

The general requirements for trespass to the person are direct, ${ }^{62}$ positive, intentional conduct, ${ }^{63}$ resulting in immediate harm, but damage need not be

60 See Neethling and Potgieter Law of Delict 25; Van der Walt and Midgley Principles of Delict 90-91; Loubser and Midgley Law of Delict 96.

61 Trespass in short refers to a specific wrong (Steele Tort Law 39).

62 See Sterman v EW \& W J Moore Ltd 19701 QB 596. An example of "directness" with regard to battery is a blow to the face. With regard to assault (where physical contact is not required) threatening telephone calls will fall under "directness" and with regard to false imprisonment, physical arrest by the police will be considered as "direct". Also see Peel and Goudkamp Winfield and Jolowicz on Tort 56; Witting Street on Torts 251, 256-257.

63 Initially intention was not required, but after Fowler $v$ Lanning 19591 QB 426 and Letang $v$ Cooper 19651 QB 232 (dealing with battery), it is clear that in trespass to the person, intention also including "subjective recklessness" is required (Peel and Goudkamp Winfield and Jolowicz on Tort 56-57). It has been argued that it has not yet been ruled out that liability in the tort of trespass to the person may stem from negligent conduct - see Weaver v Ward 161780 ER 284 and Scott $v$ Shepherd 1773 96 ER 525. It is important to note that in English law harm is required in the tort of 
proven. ${ }^{64}$ With regard to trespass to the person, the aim is to protect the claimant's legally recognised interest in his person from wrongful interference by the defendant which may lead to compensation. ${ }^{65}$ Thus interference with a person may take place in the form of battery, assault, and false imprisonment. ${ }^{66}$

\subsubsection{Battery 67}

Battery is an act by the "defendant that directly and intentionally" causes harm to the claimant through some kind of unlawful, non-consensual, undesired, physical contact. ${ }^{68}$ According to the requirements, there must be direct, physical, "hostile"69 contact which is not consented to. ${ }^{70}$ Bodily contact will not be considered hostile if it conforms to the ordinary, generally acceptable contact that occurs in everyday life, such as brushing against someone in a crowded corridor. ${ }^{71}$ There must be a voluntary, ${ }^{72}$ intentional,

negligence while it is not important in trespass to a person. Furthermore, there are different prescription periods with regard to claims in trespass and negligence. Cf Murphy "Trespass to the Person" 1093; Witting Street on Torts 251-254; Giliker Tort 409; McBride and Bagshaw Tort Law 42-45; Steele Tort Law 40-47; Lunney, Nolan and Oliphant Tort Law 43-53.

64 The tort is actionable per se. See Peel and Goudkamp Winfield and Jolowicz on Tort 57; Deakin, Johnston and Markesinis Markesinis and Deakin's Tort Law 359; Giliker Tort 409. Deakin, Johnston and Markesinis Markesinis and Deakin's Tort Law 360; Giliker Tort 409.

$66 \quad$ Murphy "Trespass to the Person" 1092.

67 Usually referred to as assault in other jurisdictions (Giliker Tort 414). See Witting Street on Torts 249. Cf Murphy "Trespass to the Person" 1092; Deakin, Johnston and Markesinis Markesinis and Deakin's Tort Law 362; Steele Tort Law 33.

This was enunciated in Wilson v Pringle 1987 QB 237, but really refers to some kind of "offensive" conduct as submitted by Peel and Goudkamp Winfield and Jolowicz on Tort 60. Cf Witting Street on Torts 254 who refers to conduct that "the claimant might object to, something that the claimant might regard as an unlawful intrusion on his rights to physical integrity". Lord Goff in Fv West Berkshire HA 19902 AC 1, 73 did not approve of the correctness of the use of term "hostile". Cf McBride and Bagshaw Tort Law 43-44; Lunney, Nolan and Oliphant Tort Law 53-56. Whether or not there was consent will be determined objectively. The claimant must prove that he did not consent (Frieman v Home Office (No 2) 1983 All ER 589, 594595). See Peel and Goudkamp Winfield and Jolowicz on Tort 61; Murphy "Trespass to the Person" 1143; Witting Street on Torts 255.

71 See Collins $v$ Wilcock 19841 WLR 1172, 1178-1179; $F v$ West Berkshire Health Authority 19892 All ER 545, 564; Wainwright v Home Office 20042 AC 406, 417; Peel and Goudkamp Winfield and Jolowicz on Tort 58-59, 60 fn 35; Murphy "Trespass to the Person" 1096; Deakin, Johnston and Markesinis Markesinis and Deakin's Tort Law 362-363; Witting Street on Torts 254, 72-73; Giliker Tort 413; Steele Tort Law 47-49. McBride and Bagshaw Tort Law 38-39. 
positive act by the defendant ${ }^{73}$ and the consequences need not be foreseeable. ${ }^{74}$

For example, in Morris $v$ Marsden ${ }^{75}$ the defendant (a schizophrenic) attacked the defendant and claimed that because of his condition he did not understand the consequences of his conduct. The defendant was found liable in the tort of battery as his actions were voluntary at the time the tort was committed. Stable $\mathrm{J}^{76}$ stated that if a person was in a complete state of automatism, which is in English law acting without fault in causing the harm, then he will not be held liable. ${ }^{77}$

The influence of reasonableness is implicit on voluntariness. In principle, if the defendant's conduct is involuntary then an element may be absent or a defence to battery may be applicable. The conduct required is direct, physical, unlawful, non-consensual contact. If a person is reasonably expected to endure the direct, physical, voluntary contact or if the contact is inconsequential then there is no battery.

\subsubsection{Assault}

Assault is a positive act by the defendant that intentionally and directly "causes the claimant reasonably to apprehend the imminent infliction of battery". ${ }^{78}$ Thus there must be voluntary conduct (on the part of the defendant) which leads to the claimant's fear or reasonable anticipation of imminent, unlawful violence by the defendant. ${ }^{79}$ Actual physical contact is not required. Thus if $X$ points a gun at $Y$ and misses the shot at $Y$, then $X$ has committed assault, but if $Y$ gets shot then it is battery. ${ }^{80}$

Inciting words are usually not considered as assault, but in $R v$ Ireland ${ }^{b 1}$ the House of Lords held that verbal threats received telephonically leading the plaintiff to reasonably believe that the threats would be carried out

73 Obstructing an entrance or standing in a person's way is not sufficient. See Witting Street on Torts 255-256.

$74 \quad$ See Peel and Goudkamp Winfield and Jolowicz on Tort 58; Murphy "Trespass to the Person" 1094; Giliker Tort 412.

75 Morris v Marsden 1952 All ER 925.

$76 \quad$ Morris v Marsden 1952 All ER 925, 927.

77 Witting Street on Torts 659.

78 See Collins v Wilcock 19841 WLR 1172, 1178, Witting Street on Torts 249; Murphy "Trespass to the Person" 1092; Steele Tort Law 35; Lunney, Nolan and Oliphant Tort Law 49.

79 See Deakin, Johnston and Markesinis Markesinis and Deakin's Tort Law 359, 361.

$80 \quad$ See Giliker Tort 414

$81 \quad R v$ Ireland 1998 AC 147 . Even though this was a criminal case, the reasoning may be applied to assault as a tort. 
immediately qualified as an assault. ${ }^{82}$ In Read $v$ Cocker ${ }^{83}$ the defendant was found liable for assault when he made a gesture and threatened to break the plaintiff's neck if he did not leave the shop. ${ }^{84}$

The influence of reasonableness on the requirement of some form of voluntary, positive conduct on the part of the defendant which leads to the claimant's reasonable apprehension of imminent battery is explicit. It would also be unreasonable to hold the defendant liable for involuntary conduct. Furthermore, if conduct on the part of the defendant is absent, then there is no tort and it would be unreasonable to hold the defendant liable.

\subsubsection{False imprisonment}

False imprisonment refers to the act of the defendant who intentionally and directly "causes the claimant's confinement within an area delimited by the defendant". ${ }^{85}$ The conduct must usually consist of a voluntary, positive act, ${ }^{86}$ and must be intentional, ${ }^{87}$ direct and immediate. ${ }^{88}$

The influence of reasonableness is implicit on the requirement of positive conduct on the part of the defendant that leads to the confinement of the plaintiff. It would be unreasonable to hold the defendant liable if there was

$82 \quad R v$ Ireland 1998 AC 147, 162. See Peel and Goudkamp Winfield and Jolowicz on Tort 65; Witting Street on Torts 258-259; Lunney, Nolan and Oliphant Tort Law 5053.

83 Read v Cocker 138 ER 1437.

84 See McBride and Bagshaw Tort Law 40; Giliker Tort 416.

85 Confinement need not be limited to a prison cell or room. See Murphy "Trespass to the Person" 1092, 1104; Deakin, Johnston and Markesinis Markesinis and Deakin's Tort Law 370; Witting Street on Torts 249, 264.

86 For example, if the public authority omits to release a claimant, it will not necessarily amount to false imprisonment unless the claimant has the right to be released and the defendant is obliged to release the claimant. See lqbal $v$ Prison Officers Association 2010 QB 732, where the prison warders went on strike and did not release the claimant at the time the strike was going on. At the time, the Governor ordered that the prisoners remain in their cells throughout the day while the strike was going on. A failure by the prison warders to turn up to work did not lead to liability for false imprisonment. However, a deliberate dishonest refusal might lead to a claim for (omission) misfeasance in public office (per Lord Neuberger MR paras 40-42). In Roberts $v$ Chief Constable of the Cheshire Constabulary 1999 WLR 662 , the claimant was arrested on suspicion of burglary and detained without review for over two hours longer than the period authorised by the statute. His detention of approximately 2 hours 20 minutes was considered unlawful and he was found to have been falsely imprisoned for that time. See Deakin, Johnston and Markesinis Markesinis and Deakin's Tort Law 372; Witting Street on Torts 269; McBride and Bagshaw Tort Law 41, 59; Giliker Tort 416; Steele Tort Law 63-64.

87 See lqbal v Prison Officers Association 2010 QB 732 para 72; McBride and Bagshaw Tort Law 45.

$88 \quad$ Giliker Tort 417. 
no voluntary, intentional, positive act on the part of the defendant which leads to the confinement of the plaintiff.

\subsection{The tort of negligence}

In the tort of negligence, ${ }^{89}$ the criterion applied is the reasonable person standard. It has been held that the reasonable person may have certain conditions such as a condition leading to a heart attack, ${ }^{90}$ and that such a person who is unaware of his condition cannot be held liable for the harm he caused as a result of the condition. ${ }^{91}$

It is evident that English law, in a sense, has influenced South African law, as an approach similar to that in English law has been followed in determining whether there was any prior fault-related voluntary conduct. English tort law refers to the reasonable person as the hypothetical ordinary person who may have a condition such as a heart attack leading to mechanical acts (where there was no prior fault-related act) causing harm. In such instances there is no fault and therefore no liability in the tort of negligence. In the South African law of delict, conduct would be absent as the conduct is involuntary, as well as fault, providing there was no prior faultrelated voluntary conduct which led to the subsequent involuntary act.

It is apparent that in English law the defence of automatism (that is, acting without fault) is therefore applicable in the tort of negligence and the intentional torts. It is unreasonable for the defence of automatism to apply where prior negligent or intentional voluntary acts subsequently lead to involuntary acts resulting in harm to another. Thus, it is reasonable for the defence of automatism to apply if there were no prior negligent or intentional acts leading to involuntary conduct causing harm.

A person who is unaware of his condition and, for example, suffers a heart attack which leads to mechanical movements resulting in harm or loss, may not reasonably be held to have capacity or be liable in the tort of negligence. Capacity "refers to the status of legal persons and their ability to sue or be sued in tort". 92

89 The tort of negligence will be discussed in more detail in later contributions still to be published (see fn 1).

$90 \quad$ See Waugh v James K Allen Ltd 19642 Lloyd's Rep 1; Peel and Goudkamp Winfield and Jolowicz on Tort 779.

$91 \quad$ See Mansfield $v$ Weetabix Ltd 19981 WLR 1263; Peel and Goudkamp Winfield and Jolowicz on Tort 779; see para 3 above, where a similar approach has been applied in South African law where a person suffered a heart attack.

92 Witting Street on Torts 651. 
With regard to the tort of negligence, conduct is not explicitly referred to as a requirement but some form of conduct is required, that is in the form of an omission, a failure to act, in order to ground liability. ${ }^{93}$ In Anglo-American law the term "misfeasance" refers to affirmative or positive action, synonymous with the term "commission" used in South African law, while "nonfeasance" refers to a failure to act $^{94}$ and is synonymous with the term "omission" used in South African Law. As stated above ${ }^{95}$ the conduct must be voluntary, whether one is dealing with an intentional tort or the tort of negligence. The tort of negligence specifically deals with negligently inflicted harm. ${ }^{96}$ It protects a number of interests and focusses on the conduct of the defendant and whether the defendant acted unreasonably in causing the plaintiff's harm or loss. ${ }^{97}$

In English law, under the tort of negligence "omissions" are recognised as a specific category of the duty of care. This category of duty will be discussed in detail in a future contribution as it deals more with the other elements of a tort than with the requirement of conduct. ${ }^{98}$ For the purposes of this contribution it is sufficient to point out that conduct in the form of an omission is required when determining liability in the tort of negligence. Thus, in respect of negligence a failure to act may lead to liability in the tort of negligence, provided all the other elements are also present.

In South African law, conduct in the form of an omission is still regarded as conduct which may lead to liability in delict if the remaining elements required are also present. 99 The influence of reasonableness on some form of conduct in English law is implicit in that it is unreasonable to hold a person liable under the tort of negligence if there was a failure to act/nonfeasance.

93 The elements required for the tort of negligence are duty, breach, causation and damage. See Deakin, Johnston and Markesinis Markesinis and Deakin's Tort Law 99. Cf Jones "Negligence" 441; Peel and Goudkamp Winfield and Jolowicz on Tort 78; Witting Street on Torts 25; Steele Tort Law 112. The influence of reasonableness on the other elements of the tort of negligence will be discussed further in later contributions still to be published (see fn 1). In this contribution the focus is on some form of conduct. See Deakin, Johnston and Markesinis Markesinis and Deakin's Tort Law 178; Witting Street on Torts 40; Keeton et al Prosser and Keeton on the Law of Torts 374. In paras 4.1.1-4.1.3 above.

96 However, negligently inflicted harm does not always result in liability in negligence. For example, negligent conduct with respect to the use of land could result in nuisance liability (Witting Street on Torts 26). McBride and Bagshaw Tort Law 95.

98 See fn 1.

99 See para 3 above. 


\section{The influence of reasonableness on conduct in American law}

\subsection{The intentional torts of trespass to the person}

Generally, the torts of trespass to a person require some kind of positive, physical act. ${ }^{100}$ The torts are actionable per se. That is, proof of physical harm is not required (in contrast to the tort of negligence where proof of harm is required) and the plaintiff is in principle entitled to damages. ${ }^{101}$

\subsubsection{Battery}

According to the requirements, there must be an intentional positive (affirmative) act, ${ }^{102}$ resulting in harm or offense to the plaintiff or another that is not privileged or consented to. ${ }^{103} \mathrm{In}$ terms of the act, such an act must be voluntary. ${ }^{104}$ Involuntary acts such as muscle spasms, fits and so forth do not qualify as acts. ${ }^{105}$ However, an instinctive response to an emergency such as grabbing a person's arm or striking a person out of "insane impulses"106 constitutes an act. Contact or touch must be substantial or significant and it is interpreted widely. For example, contact is present where a person drinks poison placed in a cup, ${ }^{107}$ is exposed to dangerous fumes, ${ }^{108}$ or radiation, or smoke from tobacco, provided there is a "purpose

100 Dobbs, Hayden and Bublick Hornbook on Torts 54.

101 Dobbs, Hayden and Bublick Hornbook on Torts 54.

102 See American Law Institute Restatement Second of Torts $1965 \S 13$ (1965); American Law Institute Restatement Third of Torts $2015 \S 101 \mathrm{cmt}$ c; Dobbs, Hayden and Bublick Hornbook on Torts 68-69; Keeton et al Prosser and Keeton on the Law of Torts 41. The Restatement of Torts is an extensive, successive body of work produced by the American Law Institute that is aimed at gathering and combining black letter law applied throughout the different states. The volumes include case law, restate existing common law, and provide guidance on what the rule of law should be to the legal community. Although the Restatements are not binding on the courts, they are regarded as authoritative and are often referred to in judgments (Zweigert and Kötz Introduction to Comparative Law 41, 251). The First, Second or Third Restatement of Torts may be referred to in order to show similarities or changes between the volumes which are often highlighted by American academic writers.

103 See American Law Institute Restatement Second of Torts 1965§ 13; Dobbs, Hayden and Bublick Hornbook on Torts 62-64.

104 See American Law Institute Restatement Second of Torts $1965 \S 2$.

105 Keeton et al Prosser and Keeton on the Law of Torts 34-35.

106 Poltmatier v Russ 537 A 2d 468 (1988); Dobbs, Hayden and Bublick Hornbook on Torts 68.

107 Snouffer $v$ Snouffer 621 NE 2d 879 (Ohio Ct App 1933). See Dobbs, Hayden and Bublick Hornbook on Torts 67.

108 Swope $v$ Columbian Chems Co $281 \mathrm{~F} 3 \mathrm{~d} 185$ (5 $5^{\text {th }}$ Cir 2002). See Dobbs, Hayden and Bublick Hornbook on Torts 67 fn 95. 
to harm or offend" on the part of the defendant. ${ }^{109}$ Examples of battery include instances where the defendant shoots or beats a spouse; ${ }^{110}$ spits on the plaintiff's face; ${ }^{111}$ pushes the plaintiff aggressively even though the plaintiff is not physically harmed; ${ }^{112}$ kisses the plaintiff without consent; ${ }^{113}$ touches the plaintiff's clothing, ${ }^{114}$ body ${ }^{115}$ or hair when not wanted to do so; ${ }^{116}$ snatches an object from the plaintiff's hand $;{ }^{117}$ intentionally pulls a chair from underneath the plaintiff as she is about to sit resulting in her falling to the floor; ${ }^{118}$ and where the defendant provides medical treatment which involves physical contact without consent, even if the treatment was intended to save the patient's life. ${ }^{119}$

The influence of reasonableness on conduct in the tort of battery is implicit. There must be positive conduct on the part of the defendant in the form of touching or contact with the plaintiff. Contact is interpreted widely and may occur directly or indirectly. The conduct must be voluntary. That is, the defendant must be able to mentally control his muscular movements when there is contact with the plaintiff. Thus, if the conduct is involuntary then there is no act and it is unreasonable to hold the defendant liable. If the contact is accidental then intention is absent and it is unreasonable to hold

109 Field v Philadelphia Elec Co 388 Pa Super 400, 417, 565 A 2d 1170, 1178 (1989).

$110 \quad$ Noble v Noble 761 P 2d 1369 (Utah 1988); Cain v McKinnon 552 So 2d 91 (Miss 1989); Dobbs, Hayden and Bublick Hornbook on Torts 61.

111 See Draper v Baker 61 Wis 450, 21 NW 527 (1884); Keeton et al Prosser and Keeton on the Law of Torts 41.

112 Whitley $v$ Anderson 37 Colo App 486, 551 P 2d 1083 (1976), aff'd, 194 Colo 87, 570 P 2d 525 (1977); Selmeczki v New Mexico Dep't of Corrections 139 NM 122, 129 P 3d 158 (Ct App 2006); Dobbs, Hayden and Bublick Hornbook on Torts 61-62.

113 Johnson v Ramsey County, 424 NW 2d 800 (Minn Ct App 1988); Dobbs, Hayden and Bublick Hornbook on Torts 61 fn 54.

114 Piggly-Wiggly Alabama Co v Rickles 1925212 Ala 585, 103 So 860, where there was an attempted search of the plaintiff's pockets. See Keeton et al Prosser and Keeton on the Law of Torts 39.

115 Stockett $v$ Tolin 791 F Supp 1536 (SD Fla 1992), where the employer touched the employee's breast and licked her; White $v$ University of Idaho 797 P 2d 108, 109 (Idaho 1990), where the piano teacher touched the plaintiff's back as if lifting his fingers on and off the piano; Dobbs, Hayden and Bublick Hornbook on Torts 62 fn 62.

116 Rogers v Loews L'Enfant Plaza Hotel 526 F Supp 523 (DDC 1981); Dobbs, Hayden and Bublick Hornbook on Torts 61 fn 54.

117 See Fisher v Carrousel Motor Hotel Inc Tex (1967) 424 SW 2d 627, 629-630 where a plate was snatched from the plaintiff's hand; Keeton et al Prosser and Keeton on the Law of Torts 40.

118 Garratt v Dailey 46 Wash 2d 197, 279 P 2d 1091 (1995); Dobbs, Hayden and Bublick Hornbook on Torts 68.

119 See Taylor v Johnston 985 P 2d 460 (Alaska 1999); Mims v Boland 110 Ga App 477, 138 SE 2d 902 (1964); Dobbs, Hayden and Bublick Hornbook on Torts 61 fn 55. 
the defendant liable for battery. The tort of negligence may, however, be applicable.

\subsubsection{Assault}

Assault usually occurs before battery, and is "an act that is intended to and does place the plaintiff in apprehension of an immediate unconsented-to touching that would amount to a battery". ${ }^{120}$ The Restatement Second of Torts refers to "apprehension"121 while the Restatement Third of Torts refers to "anticipation". ${ }^{122}$ The courts sometimes refer to "fear". ${ }^{123}$ Subjective anticipation or apprehension of harm is required on the part of the plaintiff. ${ }^{124}$ A claim for assault (as in English law) is based on the lack of physical contact or harm. Thus, if there is physical contact then it may be regarded as a battery. ${ }^{125}$ The plaintiff must be aware of the impending harm. ${ }^{126}$ Without such awareness there is no assault, but if the plaintiff is subsequently harmed then there may be a battery. ${ }^{127}$

An example of assault occurs where the defendant intends to scare the plaintiff by shooting at him but not intending for the bullet to strike him. In Raess $v$ Doescher, ${ }^{128}$ even though there was no attempt to strike the plaintiff, the plaintiff's belief in an imminent strike was reasonable, considering that the defendant "aggressively and rapidly advanced on the plaintiff with clenched fists, piercing eyes, beet-red face, popping veins",

120 Dobbs, Hayden and Bublick Hornbook on Torts 69

121 American Law Institute Restatement Second of Torts $1965 \S 21$ and $\S 32$.

122 American Law Institute Restatement Third of Torts 2015 §105; Dobbs, Hayden and Bublick Hornbook on Torts 69.

123 See Lamb v State 93 Md App 422, 438, 613 A 2d 402, 409 (1993); American Law Institute Restatement Third of Torts 2015 \$105 illus 1; American Law Institute Restatement Second of Torts $1965 \S 24 \mathrm{cmt} \mathrm{B}$ and illus 1 and 2; Dobbs, Hayden and Bublick Hornbook on Torts 70-71.

124 See Chavez v Thomas \& Betts Corp 396 F 3d 1088, 1101 (10 th Cir 2005), where comments on the plaintiff's bra followed by a physical touching and reaching over to open her shirt could easily be deemed as apprehension of imminent battery. See Dobbs, Hayden and Bublick Hornbook on Torts 69; Shapo Principles of Tort Law 30 fn 7.

125 See Bowie v Murphy 271 Va 127, 624 SE 2d 74 (2006); Dobbs, Hayden and Bublick Hornbook on Torts 69-70.

126 See American Law Institute Restatement Second of Torts 1965 § 22; Keeton et al Prosser and Keeton on the Law of Torts 44.

127 See McCraney v Flanagan 47 NC App 498, 267 SE 2d 404 (1980), where the plaintiff awoke and found that the defendant had had sexual intercourse with her. Due to the fact that she had been unaware of the imminent sexual assault, she had not been assaulted.

$128 \quad$ Raess $v$ Doescher 883 NE 2d 790 (Ind 2008). See Dobbs, Hayden and Bublick Hornbook on Torts 72. 
screamed, swore at him, and backed him up against a wall. ${ }^{129}$ If the plaintiff anticipates an imminent battery then there is an assault. ${ }^{130}$ Other examples of assault include shaking a fist under the plaintiff's nose, ${ }^{131}$ aiming a weapon at a person, ${ }^{132}$ and chasing a person with intent to harm. ${ }^{133}$

It was previously thought that words without actual physical conduct do not constitute assault, ${ }^{134}$ however, words are now considered in context and may, depending on the circumstances, constitute "assault". ${ }^{135}$ For example, in Cullison $v$ Medley ${ }^{136}$ the defendants entered the plaintiff's home one evening after he retired to bed. They accused and berated him while one of the defendant's repeatedly slapped at a gun which was in a holster on his thigh but did not draw it. The court found that in the light of all the facts, there was an assault. ${ }^{137}$

The influence of reasonableness on assault is implicit. The conduct must be in the form of an intentional, voluntary, positive act. Through his actions or words the defendant must cause the plaintiff to subjectively fear, anticipate or apprehend an immediate, direct, unjustified battery. It would be unreasonable to hold the defendant liable for conduct which is not deemed voluntary. Furthermore, if conduct on the part of the defendant is absent, then no tort has been committed.

\subsubsection{False imprisonment}

False imprisonment infringes on the plaintiff's freedom of movement, and such a restriction of movement by the defendant may occur in a direct or

129 Dobbs, Hayden and Bublick Hornbook on Torts 72.

130 Dobbs, Hayden and Bublick Hornbook on Torts 70.

131 See Stockwell v Gee 1926121 Okl 207, 249 P 389; Keeton et al Prosser and Keeton on the Law of Torts 43.

132 See Holdorf $v$ Holdorf 1918185 lowa 838, 169 NW 737 (threatening with a club); Keeton et al Prosser and Keeton on the Law of Torts 43.

133 See Townsdin v Nutt 187719 Kan 282, where the defendant rode towards the plaintiff intending to run her down; Keeton et al Prosser and Keeton on the Law of Torts 43.

$134 \quad$ Webbier $v$ Thoroughbred Racing Protective Bureau Inc 105 RI 605, 614, 254 A 2d 285, 290 (1969).

135 See Muslow v AG Edwards \& Sons Inc 509 So 2d 1012, 1021 (La Ct App 1987); Johnson v Bollinger 86 NC App 1, 356 SE 2d 378 (1987); American Law Institute Restatement Third of Torts $2015 \S 105 \mathrm{cmt} \mathrm{g;} \mathrm{American} \mathrm{Law} \mathrm{Institute} \mathrm{Restatement}$ Second of Torts 1965 § 31; Dobbs, Hayden and Bublick Hornbook on Torts 71.

136 Cullison v Medley 570 NE 2d 27 (Ind 1991).

137 See Dobbs, Hayden and Bublick Hornbook on Torts 71 fn 131. 
indirect manner. ${ }^{138}$ The defendant must intend ${ }^{139}$ to confine (detain or restrain) ${ }^{140}$ or instigate the confinement of the plaintiff against the plaintiff's will. ${ }^{141}$ False arrest is similar to false imprisonment except that in false arrest, the arrest is executed by an officer or a person authorised to make an arrest. ${ }^{142}$ Confinement for even the shortest period of time is sufficient. ${ }^{143}$ Arrest, threats, duress or physical force may be used to confine a person. ${ }^{144}$

Examples of false imprisonment include a patient's being held against his will at an institute for substance abuse, ${ }^{145}$ the driver of a motor vehicle not allowing a passenger to get out of the vehicle, ${ }^{146}$ and a police officer detaining the plaintiff without a warrant or "probable cause".

The influence of reasonableness on the requirement of a positive voluntary act leading to the confinement of the plaintiff is implicit. The restriction of the plaintiff's freedom of movement may be caused directly or indirectly. The conduct must be in the form of the voluntary, intentional, confinement of the plaintiff, or it would be unreasonable to hold the defendant liable for this tort. Furthermore, without the positive act on the part of the defendant of causing the confinement of the plaintiff, there is no tort of false imprisonment.

\subsection{The tort of negligence}

In American law, as in English law, conduct is not referred to as a specific requirement, but conduct in the form of an omission/nonfeasance is required.

In American law, as in English law, in instances where a person is "reasonably unaware" of his own disability or physical limitation, such as

138 Dobbs, Hayden and Bublick Hornbook on Torts 77. Cf Keeton et al Prosser and Keeton on the Law of Torts 47.

139 Accidental confinement by the defendant is not construed as intentional confinement. See Adams v Wal-Mart Stores Inc 324 F 3d 935, 941 (7th Cir 2003); Dobbs, Hayden and Bublick Hornbook on Torts 73 fn 150.

140 See American Law Institute Restatement Second of Torts $1965 \S 35$, where all these terms may be used with regard to false imprisonment.

141 See Keeton et al Prosser and Keeton on the Law of Torts 47, 52-53.

142 Dobbs, Hayden and Bublick Hornbook on Torts 73.

143 See Strain v Irwin 1915195 Ala 414, 70 So 734; Fuerschbach v Southwest Airlines Co 439 F 3d 1197 (10 th Cir 2006) 1208; Dobbs, Hayden and Bublick Hornbook on Torts 74; Keeton et al Prosser and Keeton on the Law of Torts 48.

144 See American Law Institute Restatement Second of Torts $1965 \S \S 40$ and 41.

145 See Collins v Straight Inc $748 \mathrm{~F} 2 \mathrm{~d} 916$ (4th Cir 1984); Geddes v Daughters of Charity of St Vincent de Paul Inc 348 F 2d 144 (5 $5^{\text {th }}$ Cir 1965); authority cited by Dobbs, Hayden and Bublick Hornbook on Torts 74 fn 164.

146 See Noguchi v Nakamura 2 Haw App 655, 638 P 2d 1383 (1982); Sindle v New York City Transit Auth 33 NYS 2d 183, 307 NE 2d 245 (1973); Dobbs, Hayden and Bublick Hornbook on Torts 74. 
where a person suffers a heart attack and was not aware of his condition, even though there is conduct he may not be held liable because the heart attack was unforeseeable. ${ }^{147}$ The same applies where a person sustains a stroke or an epileptic fit, or faints. ${ }^{148}$ A person who is aware of his condition, disability or physical impairment, or can reasonably foresee that he is prone to such impairment, such as a person prone to seizures, may be held negligent for not controlling the seizures. ${ }^{149}$

A person who voluntarily consumes alcohol ${ }^{150}$ is still judged according to the standard of the sober, reasonable person. ${ }^{151}$ The reason for this is that it would be common for a defendant to raise the excuse of intoxication. Drunkenness is not encouraged in society, and a person who consumes alcohol should be held accountable for the consequences of consuming alcohol and causing harm. ${ }^{152}$

A mental impairment, incapacity or disability will generally not lead to the exclusion of liability in the tort of negligence or the intentional torts. ${ }^{153}$ Keeton et all54 point out that this was the way the law developed and the person with a mental impairment or insane person is still judged according

147 See Baker $v$ Joyal 4 AD 3d 596, 771 NYS 2d 269 (2004); Hancock-Underwood $v$ Knight 670 SE 2d 720 (Va 2009); American Law Institute Restatement Third of Torts 2010; Dobbs, Hayden and Bublick Hornbook on Torts 224.

148 See Moore v Preenell 197738 Md App 243, 379 A 2d 1246 and Frechette $v$ Welch (1st Cir 1980) 621 F 2d 11 (with regard to an unforeseeable blackout); Keeton et al Prosser and Keeton on the Law of Torts 162.

149 See Goodrich v Blair 132 Ariz 459, 646 P 2d 890 (1982), where a driver was prone to heart attacks; Lutzkovitz v Murray 339 A 2d 64, 93 ALR 3d 321 (Del 1975) in respect of the risk of having blackouts; Howle v PYA/Monarch Inc 288 SC 586, 344 SE 2d 157 (1986) in respect of fatigue and drowsiness due to insulin resistance. Thus, where the defendant is aware of his condition and continues to drive or operate machinery thereafter causing an accident or harm, then such a person's conduct is considered unreasonable. See Dobbs, Hayden and Bublick Hornbook on Torts 225 fn 157-159.

150 A person who is involuntarily intoxicated is not judged according to the reasonable person standard. See Davies v Butler 95 Nev 763, 602 P 2d 605 (1979); American Law Institute Restatement Third of Torts $2010 \S 12 \mathrm{cmt}$ c; Dobbs, Hayden and Bublick Hornbook on Torts 231 fn 209.

151 See for example, Hamilton v Kinsey Ala 1976337 So 2d 344; Haber v County of Nassau 577 F 2d 322 (2nd Cir 1977) in respect of drugs; American Law Institute Restatement Second of Torts $1965 \S 283 \mathrm{C} \mathrm{cmt} \mathrm{d;} \mathrm{Keeton} \mathrm{et} \mathrm{al} \mathrm{Prosser} \mathrm{and} \mathrm{Keeton}$ on the Law of Torts 178; Dobbs, Hayden and Bublick Hornbook on Torts 232; Epstein Cases and Materials on Torts 122.

152 See Keeton et al Prosser and Keeton on the Law of Torts 178.

153 See McGuire v Almy 8 NE 2d 760 (Mass 1936); Polmatier v Russ 537 A 2d 468 (Conn 1988); Williams v Kearby 775 P 2d 670 (Kan App 1989); Restatement Second of Torts $\S 895 \mathrm{~J}$ (1979); American Law Institute Restatement Third of Torts $2010 \S 11$ (c); Epstein Cases and Materials on Torts 50. Keeton et al Prosser and Keeton on the Law of Torts 177. 
to the standard of the reasonable person. ${ }^{155}$ Holding insane persons to a standard that they cannot meet has been criticised. ${ }^{156}$ The reasons for holding them to the reasonable person standard include that it is difficult to differentiate between one's bad judgment and one's mental incapacity; that it is fair to the plaintiff to receive compensation for harm done to him; that it will encourage those who are charged with the care of the mentally incapacitated to take care of them and control them with more care; ${ }^{157}$ and that it is costly to determine the capabilities of a person with a mental impairment. ${ }^{158}$ Dobbs, Hayden and Bublick ${ }^{159}$ refer to two cases that have applied as exceptions to the general rule. In one of them a court in Wisconsin ${ }^{160}$ held that a person cannot be held liable for conduct as a result of a sudden unforeseeable insanity and in the other, a court in New York ${ }^{161}$ found a defendant who became insane "as a result of extraordinary efforts to protect the plaintiff" not liable. The standard of care applied to a mentally incapacitated person, whether he is suffering a mental impairment ${ }^{162}$ or insanity ${ }^{163}$ etc, remains the standard of the reasonable person, not the standard of the reasonable person affected by a mental deficiency or insanity.

It is reasonable not to hold a person liable who is unaware of his own disability or physical limitation, as the condition was reasonably unforeseeable. This approach is applied in English law and in a sense followed in South African law. An anomaly applies in American law to persons with mental illnesses or mental impairments, where such subjective illness or impairment is not considered in adjusting the standard or nullifying the requirement of conduct. Such persons are in a sense held strictly liable. Even though reasons have been provided, and holding such person to the

155 See for example, Kuhn v Zabostsky 1967, 9 Ohio St 2d 129, 224 NE 2d 137; Jolley $\checkmark$ Powell Fla App 1974299 So 2d 647; American Law Institute Restatement Second of Torts $1965 \S 283 \mathrm{~B} \mathrm{cmt} \mathrm{b;} \mathrm{cases} \mathrm{cited} \mathrm{by} \mathrm{Keeton} \mathrm{et} \mathrm{al} \mathrm{Prosser} \mathrm{and} \mathrm{Keeton} \mathrm{on} \mathrm{the}$ Law of Torts fn 32; Epstein Cases and Materials on Torts 120.

156 See Alexander and Szasz 1967 Notre Dame L Rev 24; authority cited by Keeton et al Prosser and Keeton on the Law of Torts $177 \mathrm{fn} 33$.

$157 \quad$ Keeton et al Prosser and Keeton on the Law of Torts 177.

158 Green and Cardi "Basic Questions of Tort Law" 483.

159 Dobbs, Hayden and Bublick Hornbook on Torts 225-226. Also see Keeton et al Prosser and Keeton on the Law of Torts 178.

160 Breunig v American Family Ins 45 Wis 2d 536, 173 NW 2d 619, 49 ALR 3d 179 (1970).

$161 \quad$ Williams $v$ Hays 157 NY 541, 52 NE 589 (1899).

162 Vaughan $v$ Menlove 3 Bing NC 468, 132 Eng Rep 490 (CP 1837); American Law Institute Restatement Third of Torts $2010 \S 12 \mathrm{cmt} b$; Dobbs, Hayden and Bublick Hornbook on Torts 226 fn 168.

163 See Creasy v Rusk 730 NE 2d 659 (Ind 2000); Restatement Second of Torts §§ 283B cmt b, 895J (1979); Dobbs, Hayden and Bublick Hornbook on Torts $226 \mathrm{fn}$ 169. 
reasonable person standard has been criticised, the most plausible reason is that it is fair and reasonable to compensate the innocent plaintiff.

In respect of the tort of negligence, there is generally no duty to act in cases of pure omission (nonfeasance) even if harm is foreseeable. ${ }^{164}$ The question is whether the reasonable person would have acted in the circumstances. ${ }^{165}$ In American law, just as in English law, "omissions" are regarded as a specific category of duty. For the purposes of this contribution, it is sufficient to point out with regard to American law too that conduct in the form of an omission is considered when determining liability in the tort of negligence. Therefore, a failure to act may lead to liability in the tort of negligence, provided all the other elements are also present.

The influence of reasonableness is implicit, too, on the requirement of some form of conduct in American law, as it is unreasonable to hold a defendant liable under the tort of negligence if there was no omission/nonfeasance on the part of the defendant.

\section{The influence of reasonableness on conduct in French law}

\subsection{Fait générateur (relating to the requirement of conduct) in Articles 1382 to 1383 of the French Civil Code ${ }^{166}$ (hereinafter referred to as the "CC") - relating to liability for one's own personal conduct where fault is required}

According to the requirements of delictual liability under French law, there must be a fait générateur, that is, a generating, triggering, wrongful act or event. ${ }^{167}$ There is no precise definition of fait générateur in the $C C$, but it is a requirement for liability for one's own conduct (where fault is required). ${ }^{168}$ The term "conduct" is not explicitly referred to as a requirement for delictual liability in French legal doctrine as in South African law, but some form of conduct falling within the requirement of fait générateur is necessary to ground delictual liability.

\footnotetext{
164 See for example, Williams $v$ Southern Calif Gas Co 176 Cal App $4^{\text {th }} 591,98$ Cal Rptr 3d 258 (2009); Dobbs, Hayden and Bublick Hornbook on Torts 615.

165 Dobbs, Hayden and Bublick Hornbook on Torts 618.

166 French Civil Code of 1804.

167 Galand-Carval "France" 53.

168 See Van Dam European Tort Law 57; Van Gerven, Lever and Larouche Tort Law 555-556.
} 
In order to ground liability under Articles 1382 to 1383 of the $C C$, it does not matter whether the conduct was voluntary or not. Thus an involuntary act by the defendant causing injury to the plaintiff will not negate liability. For example, in Lignon $v$ Avril, ${ }^{169}$ an inexperienced volleyball player accidentally fell down during the course of the game coincidentally kicking another player and injuring him. The injured player sued the inexperienced player. The Cour de Cassation ${ }^{170}$ held that the inexperienced player was liable even though his conduct was involuntary. ${ }^{171}$

Article 1382 generally relates to liability for conduct while Article 1383 specifically provides that "everyone is responsible for the damage caused not only by his act but also by his negligence or carelessness". ${ }^{172}$ Van Gerven, Lever and Larouche ${ }^{173}$ point out that this clause refers to liability not only for a positive act, but also for an omission. ${ }^{174}$ In French law, not only a failure to act with regard to a statutory rule, but also "a failure to act in accordance with a non-legally-binding rule of proper social conduct can also entail liability". ${ }^{175}$ An obligation to act positively in respect of delictual liability may stem from an "obligation of safety" (obligation de sécurité). ${ }^{176}$ However, French law does not place particular importance on the positive legal duty to act. Furthermore, the requirement of conduct, whether in the form of an omission or commission, in cases of fault liability is subsumed under the enquiry into faute. ${ }^{177}$ Faute in French law is a broad concept covering aspects of the elements of wrongfulness and fault as understood in the South African law of delict. ${ }^{178}$

French law in general is more favourable to the plaintiff than other legal systems. In respect of the element of conduct (as it is known in the South African law of delict) French law really requires just a factual enquiry as to whether a generating act or event is present or not. Furthermore, the source of the generating act or event may stem from a so-called "act of a thing" or

\footnotetext{
169 Cass civ 23 July 1991 90-13158, Bull civ 1991 II 210111.

170 The "Supreme Court" in France for both civil and criminal matters. See GalandCarval "Liability for Damage Caused by Others" 85.

171 Van Gerven, Lever and Larouche Tort Law 339.

172 Translated by Van Gerven, Lever and Larouche Tort Law 2.

173 Van Gerven, Lever and Larouche Tort Law 2 fn 4.

174 Also see Van Dam European Tort Law 56.

175 Van Gerven, Lever and Larouche Tort Law 281.

176 This is deemed an obligation of result (obligation de résultat) as opposed to an obligation of means (obligation de moyens). See Moréteau "Basic Questions of Tort Law" 29.

177 See Van Gerven, Lever and Larouche Tort Law 298.

178 The influence of reasonableness on the concept of faute will be discussed in later contributions still to be published (see fn 1).
} 
another person (where one is responsible for that person). ${ }^{179}$ But the custodian of the thing, or person responsible for another that caused the harm or loss, may be held strictly liable. ${ }^{180}$

It is therefore unreasonable for delictual liability to follow in France if a generating act or event is absent. The requirement of conduct's being "voluntary" involves a normative inquiry (as opposed to the factual inquiry as to whether or not there was conduct) which may lead to the negation of liability on the part of the defendant where his actions are essentially mechanical (as the mental ability to control his muscular movements is absent). It is submitted that in the French law of delict, the element of conduct is a requirement for delictual liability but in an attenuated form. This may be justified and reasonable. In French law, strict liability is more the norm and the aim is to protect and compensate the plaintiff. Defendants are in any case generally insured against delictual liability. We may take the hypothetical example that $X$, while sleepwalking, shoots at $Y$, injuring him. $Y$ as an innocent victim sustains injury and harm. It may therefore be reasonable and justified if the plaintiff receives compensation for his injury or loss. In South African law X would not be held delictually liable, as his conduct was involuntary (fault is also absent). The only instance in South African law where the voluntariness of conduct is ineffectual in negating delictual liability is if there was some prior negligent or intentional conduct on the part of the defendant that subsequently led to his involuntary conduct. ${ }^{181}$

In respect of omissions, a failure to act positively in preventing harm, for example by warning a bee-keeper that he is spraying insecticide which will affect the bees, ${ }^{182}$ or failing to provide adequate supervision and inspection at a stadium resulting in the death of a spectator, ${ }^{183}$ is unreasonable. ${ }^{184}$ The influence of reasonableness on the requirement of a generating act or event in French law is therefore implicit.

179 See Van Dam European Tort Law 57; Van Gerven, Lever and Larouche Tort Law 555-556.

180 In order to limit the scope of this contribution, strict liability in French law will not be discussed.

181 See para 3 above.

182 See Cass civ 214 June 1972 71-11318, Bull civ 1972 II 180 146, 1973 Jur 423 note Lepointe. See the discussion of this case in Van Gerven, Lever and Larouche Tort Law 308-309.

183 See CA Lyon 16 December 1988, JCP 1990 II 21510 observations Collomb.

184 The influence of reasonableness in French law for wrongful culpable conduct stemming from omissions from a comparative perspective will be discussed in a later contribution still to be published (see fn 1). 


\section{Conclusion}

In all the jurisdictions discussed in this contribution, some form of conduct, whether in the form of an omission or a commission, is required for liability in delict or tort law. Naturally, it is unreasonable to hold a person liable without conduct which results in the causing of harm or loss. The requirement of conduct is explicitly referred to in South African law and is recognised as a separate element of liability. In French law this requirement goes beyond human behaviour to encompass a generating act or event. In Anglo-American law too, even though conduct is not explicitly referred to as a requirement in the torts of trespass to a person and the tort of negligence, it must be present in order to ground liability.

As shown in South African, English and American law, the conduct must generally be voluntary. An exception applies in American law where a person's mental impairment or illness does not nullify conduct. If the conduct is involuntary, for example, where the conduct is considered mechanical, then there is no conduct and it is unreasonable to hold the wrongdoer liable. In situations where a person suffers some kind of disability, such as a sudden heart attack or a sudden blackout not caused by his own fault, then the conduct is not voluntary and fault is absent. If the defendant forgets to take his medication or deliberately does not take it thereby leading to a blackout, the principle of "prior fault" applies and the defendant may be held liable. Thus, it may be considered unreasonable to hold the person with such a condition liable, whether the element of conduct or fault is found to be absent. French law, on the other hand, does not require the conduct to be voluntary in order to ground liability under Articles 1382 to 1383 of the $C C$. Even though the reasonableness of this may be questioned, it may be understood in the light of the French pro-victim stance, the aim of compensating the victim, and the tendency to prefer strict liability over fault liability. ${ }^{185}$ 


\section{Bibliography}

\section{Literature}

Ahmed "Influence of Reasonableness"

Ahmed R "The Influence of Reasonableness on the Elements of Delictual Liability" in Potgieter JM, Knobel J and Jansen R-M (eds) Essays in Honour of Johann Neethling (LexisNexis Durban 2015) 49-61

Ahmed Explicit and Implicit Influence of Reasonableness

Ahmed R The Explicit and Implicit Influence of Reasonableness on the Elements of Delictual Liability (LLD-thesis University of South Africa 2018)

Ahmed 2019a THRHR

Ahmed R "'Reasonableness' and Related Jurisprudential Concepts in the Law of Delict" 2019 THRHR 381-391

Ahmed 2019b THRHR

Ahmed R "The Historical Development of the Concept 'Reasonableness' in the Law of Delict" 2019 THRHR 257-266

Alexander and Szas 1967 Notre Dame L Rev

Alexander GJ and Szas TS "Mental Illness as an Excuse for Civil Wrongs" 1967 Notre Dame L Rev 24-38

American Law Institute Restatement Second of Torts 1965

American Law Institute Restatement Second of Torts (American Law Institute St Paul 1965)

American Law Institute Restatement Second of Torts 1979

American Law Institute Restatement Second of Torts (American Law Institute St Paul 1979)

American Law Institute Restatement Third of Torts 2010

American Law Institute Restatement Third of Torts (Liability for Physical and Emotional Harm) (American Law Institute St Paul 2010)

American Law Institute Restatement Third of Torts 2015

American Law Institute Restatement Third of Torts (Intentional Torts to Persons) (Tentative Draft No 1 April 8 2015) (American Law Institute St Paul 2015)

Borghetti 2012 JETL

Borghetti J-S "The Culture of Tort Law in France" 2012 JETL 158-182 
Burchell Principles of Delict

Burchell JM Principles of Delict (Juta Cape Town 1993)

Deakin, Johnston and Markesinis Markesinis and Deakin's Tort Law

Deakin S, Johnston A and Markesinis B Markesinis and Deakin's Tort Law $7^{\text {th }}$ ed (Clarendon Press Oxford 2013)

Dobbs, Hayden and Bublick Hornbook on Torts

Dobbs DB, Hayden PT and Bublick EM Hornbook on Torts $2^{\text {nd }}$ ed (West St Paul MN 2016)

Epstein Cases and Materials on Torts

Epstein RA Cases and Materials on Torts $8^{\text {th }}$ ed (Aspen Law New York 2004)

Fletcher 1985 Harv L Rev

Fletcher GP "The Right and the Reasonable" 1985 Harv L Rev 949-982

Galand-Carval "France"

Galand-Carval S "France: Causation under French Law" in Spier J (ed) Unification of Tort Law: Causation (Kluwer Law The Hague 2000) 53-62

Galand-Carval "Liability for Damage Caused by Others"

Galand-Carval S "Liability for Damage Caused by Others under French Law" in Spier J (ed) Unification of Tort Law: Liability for Damage Caused by Others (Kluwer Law The Hague 2003) 85-103

Giliker Tort

Giliker P Tort $5^{\text {th }}$ ed (Sweet \& Maxwell London 2014)

Green and Cardi "Basic Questions of Tort Law"

Green MD and Cardi WJ "Basic Questions of Tort Law from the Perspective of the USA" in Koziol H (ed) Basic Questions of Tort Law from a Comparative Perspective (Jan Sramek Verlag Wien 2015) 431-514

Hahlo and Kahn South African Legal System

Hahlo HR and Kahn E The South African Legal System and its Background (Juta Cape Town 1968)

Himonga and Nhlapo African Customary Law Himonga C and Nhlapo RT (eds) African Customary Law in South Africa: Post-Apartheid and Living Perspectives (Oxford University Press Cape Town 2014) 
Jones "Negligence"

Jones MA "Negligence" in Jones MA (gen ed) Clerk and Lindsell on Torts $21^{\text {st }}$ ed (Sweet \& Maxwell London 2014) 439-607

Keeton et al Prosser and Keeton on the Law of Torts

Keeton $\mathrm{P}$ et al Prosser and Keeton on the Law of Torts $5^{\text {th }}$ ed (West St Paul MN 1984)

Koziol "Comparative Conclusions"

Koziol H "Comparative Conclusions" in Koziol H (ed) Basic Questions of Tort Law from a Comparative Perspective (Jan Sramek Verlag Wien 2015) 685-838

Loubser and Midgley Law of Delict Loubser MM and Midgley JR (eds) The Law of Delict in South Africa $3^{\text {rd }}$ ed (Oxford University Press Cape Town 2018)

Lunney, Nolan and Oliphant Tort Law

Lunney M, Nolan D and Oliphant K Tort Law: Text and Materials $6^{\text {th }}$ ed (Oxford University Press Oxford 2017)

McBride and Bagshaw Tort Law

McBride NJ and Bagshaw R Tort Law $5^{\text {th }}$ ed (Pearson Education New York 2015)

Moréteau "Basic Questions of Tort Law"

Moréteau O "Basic Questions of Tort Law from a French Perspective" in Koziol H (ed) Basic Questions of Tort Law from a Comparative Perspective (Jan Sramek Verlag Wien 2015) 3-98

Mullender 2005 MLR

Mullender $\mathrm{R}$ "The Reasonable Person, the Pursuit of Justice, and Negligence Law" 2005 MLR 681-695

Murphy "Trespass to the Person"

Murphy J "Trespass to the Person" in Jones MA (gen ed) Clerk and Lindsell on Torts $21^{\text {st }}$ ed (Sweet \& Maxwell London 2014) 1091-1173

Neethling and Potgieter Law of Delict

Neethling J and Potgieter JM Law of Delict $7^{\text {th }}$ ed (LexisNexis Durban 2015)

Peel and Goudkamp Winfield and Jolowicz on Tort

Peel E and Goudkamp J Winfield and Jolowicz on Tort $19^{\text {th }}$ ed (Sweet \& Maxwell London 2014) 
Shapo Principles of Tort Law

Shapo M Principles of Tort Law $4^{\text {th }}$ ed (West Academic Eagan MN 2016)

Steele Tort Law

Steele J Tort Law $3^{\text {rd }}$ ed (Oxford University Press Oxford 2014)

Van Dam European Tort Law

Van Dam C European Tort Law $2^{\text {nd }}$ ed (Oxford University Press Oxford 2013)

Van der Merwe and Olivier Onregmatige Daad in die Suid-Afrikaanse Reg Van der Merwe NJ and Olivier PJJ Die Onregmatige Daad in die SuidAfrikaanse Reg $6^{\text {th }}$ ed (JP van der Walt Pretoria 1989)

Van der Walt and Midgley Principles of Delict

Van der Walt JC and Midgley JR Principles of Delict $4^{\text {th }}$ ed (LexisNexis Durban 2016)

Van Gerven, Lever and Larouche Tort Law

Van Gerven W, Lever JF and Larouche P Tort Law (Hart Oxford 2000)

Visser "Compensation for Pecuniary Loss"

Visser D "Compensation for Pecuniary Loss - Actio Legis Aquiliae" in Du Bois $\mathrm{F}$ (ed) Wille's Principles of South African Law $9^{\text {th }}$ ed (Juta Cape Town 2007) $1094-1160$

Witting Street on Torts

Witting CA Street on Torts $14^{\text {th }}$ ed (Oxford University Press Oxford 2015)

Zweigert and Kötz Introduction to Comparative Law

Zweigert K and Kötz $\mathrm{H}$ Introduction to Comparative Law $3^{\text {rd }}$ ed (Clarendon Press Oxford 2011)

\section{Case law}

\section{France}

CA Lyon 16 December 1988, JCP 1990 II 21510 observations Collomb Cass civ 23 July 1991 90-13158, Bull civ 1991 II 210111

Cass civ 214 June 1972 71-11318, Bull civ 1972 II 180 146, 1973 Jur 423 note Lepointe 


\section{South Africa}

Gabellone v Protea Assurance Ltd 19814 SA 171 (O)

Government v Marine and Trade Insurance Co Ltd 19733 SA 797 (D)

Jooste v Minister of Police 19751 SA 349 (E)

Molefe v Mahaeng 19991 SA 562 (SCA)

$R v$ Dhlamini 19551 SA $120(\mathrm{~T})$

$R v$ Mkize 19592 SA $260(\mathrm{~N})$

$S v$ Arnold 19853 SA 256 (C)

S v Chretien 19811 SA $1097(\mathrm{~A})$

S v Goliath 19723 SA 1 (A)

S v Mahlinza 19671 SA $408(\mathrm{~A})$

S v Makwanyane 19956 BCLR 665 (CC)

Wessels v Hall and Pickles (Coastal) (Pty) Ltd 19854 SA 153 (C)

\section{United Kingdom}

Collins v Wilcock 19841 WLR 1172

F v West Berkshire HA 19902 AC 1, 19892 All ER 545

Fowler v Lanning 19591 QB 426

Frieman v Home Office (No 2) 1983 All ER 589

lqbal v Prison Officers Association 2010 QB 732

Letang v Cooper 19651 QB 232

Mansfield v Weetabix 19881 WLR 1263 (CA)

Morris v Marsden 1952 All ER 925

$R v$ Ireland 1998 AC 147

Read v Cocker 138 ER 1437 
Roberts v Chief Constable of the Cheshire Constabulary 1999 WLR 662

Scott $v$ Shepherd 177396 ER 525

Sterman v EW \& W J Moore Ltd 19701 QB 596

Vaughan v Menlove 3 Bing NC 468, 132 Eng Rep 490 (CP 1837)

Wainwright v Home Office 20042 AC 406

Waugh v James K Allen Ltd 19642 Lloyd's Rep 1

Weaver $v$ Ward 161780 ER 284

Wilson v Pringle 1987 QB 237

\section{United States of America}

Adams v Wal-Mart Stores Inc 324 F 3d 935, 941 (7 $7^{\text {th }}$ Cir 2003)

Baker v Joyal 4 AD 3d 596, 771 NYS 2d 269 (2004)

Bowie v Murphy 271 Va 127, 624 SE 2d 74 (2006)

Breunig v American Family Ins 45 Wis 2d 536, 173 NW 2d 619, 49 ALR 3d 179 (1970)

Cain v McKinnon 552 So 2d 91 (Miss 1989)

Chavez v Thomas \& Betts Corp 396 F 3d 1088, 1101 (10 th Cir 2005)

Creasy v Rusk 730 NE 2d 659 (Ind 2000)

Cullison v Medley 570 NE 2d 27 (Ind 1991)

Collins $v$ Straight Inc 748 F 2d 916 (4 ${ }^{\text {th }}$ Cir 1984)

Davies v Butler 95 Nev 763, 602 P 2d 605 (1979)

Draper v Baker 61 Wis 450, 21 NW 527 (1884)

Field v Philadelphia Elec Co 388 Pa Super 400, 417, 565 A 2d 1170, 1178 (1989)

Fisher v Carrousel Motor Hotel Inc Tex (1967) 424 SW 2d 627 
Frechette $v$ Welch $\left(1^{\text {st }}\right.$ Cir 1980) $621 \mathrm{~F} 2 \mathrm{~d} 11$

Fuerschbach v Southwest Airlines Co 439 F 3d 1197 (10 ${ }^{\text {th }}$ Cir 2006)

Garratt v Dailey 46 Wash 2d 197, 279 P 2d 1091 (1995)

Geddes v Daughters of Charity of St Vincent de Paul Inc 348 F 2d $144\left(5^{\text {th }}\right.$ Cir 1965)

Goodrich v Blair 132 Ariz 459, 646 P 2d 890 (1982)

Haber v County of Nassau 577 F 2d 322 (2 $2^{\text {nd }}$ Cir 1977)

Hamilton v Kinsey Ala 1976337 So 2d 344

Hancock-Underwood v Knight 670 SE 2d 720 (Va 2009)

Holdorf v Holdorf 1918185 lowa 838, 169 NW 737

Howle v PYA/Monarch Inc 288 SC 586, 344 SE 2d 157 (1986)

Johnson v Bollinger 86 NC App 1, 356 SE 2d 378 (1987)

Johnson v Ramsey County, 424 NW 2d 800 (Minn Ct App 1988)

Jolley v Powell Fla App 1974299 So 2d 647

Kuhn v Zabostsky 1967, 9 Ohio St 2d 129, 224 NE 2d 137

Lamb v State 93 Md App 422, 438, 613 A 2d 402, 409 (1993)

Lutzkovitz v Murray 339 A 2d 64, 93 ALR 3d 321 (Del 1975)

McCraney v Flanagan 47 NC App 498, 267 SE 2d 404 (1980)

McGuire v Almy 8 NE 2d 760 (Mass 1936)

Mims v Boland 110 Ga App 477, 138 SE 2d 902 (1964)

Moore v Preenell 197738 Md App 243, 379 A 2d 1246

Muslow v AG Edwards \& Sons Inc 509 So 2d 1012, 1021 (La Ct App 1987)

Noble v Noble 761 P 2d 1369 (Utah 1988)

Noguchi v Nakamura 2 Haw App 655, 638 P 2d 1383 (1982) 
Piggly-Wiggly Alabama Co v Rickles 1925212 Ala 585, 103 So 860

Polmatier v Russ 537 A 2d 468 (Conn 1988)

Raess v Doescher 883 NE 2d 790 (Ind 2008)

Rogers v Loews L'Enfant Plaza Hotel 526 F Supp 523 (DDC 1981)

Selmeczki v New Mexico Dep't of Corrections 139 NM 122, 129 P 3d 158 (Ct App 2006)

Sindle v New York City Transit Auth 33 NYS 2d 183, 307 NE 2d 245 (1973)

Snouffer v Snouffer 621 NE 2d 879 (Ohio Ct App 1933)

Stockett v Tolin 791 F Supp 1536 (SD Fla 1992)

Stockwell v Gee 1926121 Okl 207, 249 P 389

Strain v Irwin 1915195 Ala 414, 70 So 734

Swope v Columbian Chems Co $281 \mathrm{~F} 3 \mathrm{~d} 185$ (5 $5^{\text {th }}$ Cir 2002)

Taylor v Johnston 985 P 2d 460 (Alaska 1999)

Townsdin v Nutt 187719 Kan 282

Webbier v Thoroughbred Racing Protective Bureau Inc 105 RI 605, 614, 254 A 2d 285, 290 (1969)

White $v$ University of Idaho 797 P 2d 108, 109 (Idaho 1990)

Whitley v Anderson 37 Colo App 486, 551 P 2d 1083 (1976), aff'd, 194 Colo 87, 570 P 2d 525 (1977)

Williams $v$ Hays 157 NY 541, 52 NE 589 (1899)

Williams v Kearby 775 P 2d 670 (Kan App 1989)

Williams v Southern Calif Gas Co 176 Cal App $4^{\text {th }} 591$, 98 Cal Rptr 3d 258 (2009) 


\section{Legislation}

France

French Civil Code of 1804

\section{Germany}

Bürgerliches Gesetzbuch (Civil Code)

South Africa

Constitution of the Republic of South Africa, 1996

\section{United States of America}

Constitution of the USA

\section{List of Abbreviations}

CC

Harv L Rev

JETL

MLR

Notre Dame L Rev

THRHR
French Civil Code of 1804

Harvard Law Review

Journal of European Tort Law

Modern Law Review

Notre Dame Law Review

Tydskrif vir Hedendaagse RomeinsHollandse Reg 